\title{
Verdade e representação na perspectiva inversa
}

\author{
Aline Stefânia Zim
}

Aline Stefânia Zim: arquiteta, Professora do Departamento de Arquitetura da

Universidade Católica de Brasilia, doutoranda em Estética e Semiótica pela FAU/UnB e

mestre pela mesma instituição.

\section{Resumo}

Os sistemas de classificações da história da arte e da arquitetura trazem a periodização como categoria fundamental no julgamento e classificações das obras, apesar das evidências de que os artistas violavam as regras vigentes para, em nome da diferenciação e da elevação artísticas, superarem os modelos. Essa visão não só privilegia as técnicas renascentistas de representação como autênticas, como também as sacraliza, dificultando a sua leitura simbólica. O que é considerado como autêntico adquire uma função modelar, sendo menos questionado do que deveria. Por outro lado, a automatização da análise simbólica sobre as pinturas medievais, na lógica do dicionário ilustrado, dificulta a desconstrução da estrutura ideológica. As obras são classificadas mais pelas suas semelhanças, o que lhes confere um valor de gênero, e menos pelas suas particularidades. Contrapondo a visão dominante de que a arte simbólica medieval é inferior à pintura realista renascentista, Pável Floriênski propõe o conceito da perspectiva inversa, ou iconográfica, desenvolvido em 1919 a partir do estudo das pinturas dosícones russos da idade média. Essa contraposição parece resolvida pela argumentação do autor russo, mas, ao negar um sistema canônico, impõe outro, mais antigo e dominante queo primeiro. Propõe-se aqui o estranhamento da validade da perspectiva inversa como recurso de inversão, sugerindo o inverso da inversão que a perspectiva inversa propõe. Se a inversa mostra a hierarquia simbólica entre os ícones e cenário, esta émais autêntica, pois esconde menosa ordem semântica de poder. A partir do reconhecimento dos recursos artísticos é possível se fazer uma leitura laica do que é considerado sagrado em cada período. Para tanto, propõe-se o conceito de "estranhamento", desenvolvido por Chklóvsky entre os formalistas russos no início do século XX, e o recurso da leitura alegórica como procedimentos de desautomatização do olhar habitual de um objeto deslocando-o da sua identidade inicial.

Palavras-chave: Perspectiva inversa; ícones russos; estranhamento; arte e representação.

\section{Abstract}

Classification systems in the history of art and architecture bring periodization as a fundamental category in the judgment and classifications of works, despite the evidence that artists violated the rules in force, in the name of artistic differentiation and elevation, to surpass the models. This point of view privileges Renaissance techniques of representation as authentic and sacralizes them, hindering their symbolic reading. What is considered authentic acquires a modeling function, being less questioned than it should. On the other hand, the automation of symbolic analysis on medieval paintings, by the logic of the illustrated dictionary, hampers the deconstruction of the ideological structure. The works are classified more by their similarities, what gives them a value of gender, and less by their peculiarities. Contrary to the prevailing view that medieval symbolic art is inferior to realistic Renaissance painting, Pável Floriênski proposes the concept of inverse perspective, or iconographic, developed in 1919 from the study of the paintings of the Russian icons of the Middle Ages. This contraposition seems to be resolved by the Russian author's argument, but denying a canonical system imposes another, more ancient and dominant than the first. It is proposed here the estrangement of the validity of the inverse perspective as a resource of inversion, suggesting the inverse of the inversion that the inverse perspective proposes. If the inverse shows the symbolic hierarchy between the icons and scenario, it is more authentic because it hides less the semantic order of power. From the recognition of the artistic resources it is possible to make a secular reading of what is considered sacred in each period. For that, the concept of "estrangement" developed by Sklovsky among the Russian formalists at the beginning of the 20th century is proposed, as well as the use of allegorical reading as procedures to de-automate the habitual gaze of an object by displacing it from its initial identity.

Keywords: Reverse perspective; Russian icons; estrangement; art and representation. 


\section{Quem é luz, quem é sombra}

Os sistemas de classificações da história da arte e da
arquitetura automatizaram a ideia de que a idade
média é uma sombra entre dois períodos de
supremacia artística, tecnológica, científica e
filosófica. Trazem a periodização como categoria
fundamental no julgamento e classificações das
obras, mesmo sabendo que os artistas violavam as
regras vigentes para, em nome da diferenciação e da
elevação artística, superar as normas.

A periodização na história nunca é um ato neutro ou inocente: ela comete o erro de deixar outras épocas na sombra. Compreender o sistema de elaboração dos nomes e a duração dos ciclos no discurso periódico são informações importantes que revelam a natureza dos sistemas classificadores. A periodização, no entanto, não deve ser determinista; ela tem sua imagem e valores em constante mutação e evolui com a própria história. Como obra do homem, é ao mesmo tempo artificial e provisória ${ }^{1}$.

LE GOFF, Jacques. A história deve ser dividida em pedaços? São

Paulo: Editora UNESP, 2015, p.29

Idem, p.19.

3

Segundo Le Goff (2015) e Duby (1993).
As antigas periodizações, ao organizarem o tempo, tratavam basicamente dos critérios religiosos e míticos, muitas vezes baseados na interpretação metafísica da natureza. Além da observação dos astros e dos fenômenos naturais, os períodos eram definidos por eventos históricos marcados por textos sagrados, relíquias e mitos coletivos.

Os modelos de periodização vêm da tradição judaicocristã e se utilizam de números e figuras simbólicos. 0 primeiro registrado, proposto por Daniel no Antigo Testamento, utilizava a profecia de quatro animais, encarnações de quatro reinos, que representavam as quatro estações. Santo Agostinho, no livro IX da De Civitate Dei (413-427), distingue seis períodos, segundo as seis idades da vida: pequena infância (de Adão a Noé), infância (Noé a Abraão), puberdade (Abraão a Davi), juventude (Davi a Babilônia), maturidade (da Babilônia ao nascimento de Cristo) e a velhice (pós Cristo até o Juízo Final). Agostinho é contaminado pela teoria do envelhecimento do mundo: um pensamento de declínio ou pessimismo cronológico que permeava os monastérios da alta idade média e que impediu a ideia de progresso nesse período².

De todo modo, essa é uma das tantas visões que, por meio do ocultamento da verdade, se faz verdadeira. Esse é o papel das escrituras sagradas: impedir o progresso, principalmente no campo das ideias. Santo Agostinho confunde a historiografia com o Antigo Testamento, transpondo uma lógica em cima da outra.
Nessa confusão, a essência é encoberta pela aparência e o simbólico é tomado por sagrado.

A ideia de que a História deve ser organizada por rupturas periódicas é outro sintoma de um recorrente eurocentrismo infantil. Esse constante estado de ruptura mostra-se impreciso e permeado de sobreposições. O início do período que corresponde à idade média, por exemplo, é tradicionalmente marcado pela conversão do imperador Constantino ao cristianismo (Édito de Milão, 313 d. C.) ou pela remissão ao imperador de Bizâncio das insígnias imperiais ocidentais ( 476 d. C.). As referências mudam segundo a conveniência do sistema vigente.

Para os historiadores, os acontecimentos simbólicos marcam contextos específicos e compõem uma constelação de sentidos em constante reavaliação. A abordagem atual para a duração do período medieval, por exemplo, é de uma mutação que teria iniciado do século III ao VII, chamado de antiguidade tardia, na qual o renascimento do século XV seria um dos "renascimentos" recorrentes de uma longa idade média, que iria até o século XVIII (Revolução Francesa), quando finalmente teríamos os primórdios da chamada "era da modernidade"3.

A divisão da história em períodos, ciclos e séculos, inicialmente, é necessária à compreensão e à sistematização da ação humana. Há o nítido desejo da humanidade de agir sobre o tempo em longa duração pelos períodos e de dominar o tempo da vida cotidiana pelos calendários - uma combinação complexa entre continuidade e descontinuidade.

A periodização ocidental, que remonta ao pensamento grego e ao Antigo Testamento, entra tardiamente na vida cotidiana, provavelmente a partir do século XVIII, quando a História é integrada como disciplina nas escolas e universidades. $O$ ensino é a atividade fundamental para que a periodização seja instituída como elemento estruturante da cultura. Infelizmente, a revisão sobre o instituído não chega aos currículos escolares, o que torna os livros didáticos em monumentos da verdade.

Nesse contexto, a periodização histórica traz uma visão dogmática da superação de uma época sobre a outra. Entre os historiadores, há divergências sobre datas e nomes dos períodos, mas o que predomina no Ocidente é a periodização da era cristã, que considera o nascimento de Cristo como o ano "zero". A mundialização da era cristã é uma tendência recorrente e constitui a supremacia de uma visão de 
mundo sobre outras, a dizer: do sagrado sobre o pagão. Essa condição não é neutra, nem inocente, pois expressa em seus argumentos um julgamento de valor. O sagrado se desloca conforme as vontades de quem através dele tem o poder.

A modernidade no século XIX, por exemplo, torna-se referência para todos os períodos anteriores. É ali que o sistema de periodizações se consolida. Para tanto, o passado se adapta ao presente, de acordo com a visão de mundo instituída. Na mesma lógica, a idade média foi classificada a partir das referências do seu período sucessor, a idade moderna. A visão que impera é a da superação de uma cultura sobre a outra, sob o disfarce da periodização.

A supremacia de uma visão de mundo sobre as outras por recursos de elevação e de rebaixamento produz cânones consolidados pelos seus respectivos sistemas. A concepção de "idade média" traz nitidamente a conotação negativa de um período que interrompe a continuidade entre duas épocas áureas: a dos humanistas italianos e aquela com que eles se identificavam, a antiguidade clássica ${ }^{4}$.

O tempo ocidental foi medido por Roma a partir da sua fundação mítica na antiguidade e consagrada na Renascença. O que está no meio é menos importante - é apenas um meio - já que o mais elevado foi dado pela origem e pelo destino.

É recorrente no campo das artes e da arquitetura julgar as técnicas de representação a partir das referências do que já é instituído como gênero ou espécie maior. Não é por acaso que o renascimento se consolida em Florença entre os humanistas italianos, que foram ao mesmo tempo produto e produtores de si. Estes, para se elevarem enquanto precursores de uma época, criaram mecanismos para rebaixar o período anterior, assim como os artistas medievais negaram os cânones clássicos.

As obras de arte são classificadas pelos seus cânones, que antecedem e que sucedem o período subjacente. Na visão positiva, uma época supera tecnicamente a outra: tal mecanismo garante a continuidade das estruturas de poder pelos recursos da artepropaganda e da automatização da visão crítica.

\section{A violação em nome da arte}

A automatização caracteriza-se pela adequação aparente entre o pensamento, a ideologia e as técnicas de representação artísticas. Nos regimes totalitários, a ditatura é mantida pela adequação entre ideologia e realidade. As estruturas de poder pouco se revelam, já que a sua condição de permanência é o seu ocultamento. Os regimes totalitários ganharam público porque souberam manipular a linguagem pelos meios de comunicação, ou melhor, pela arte-propaganda.

Recursos de controle dos sistemas de produção e reprodução de mídias, como a censura na indústria literária ou cinematográfica, são alguns dos mecanismos da arte-propaganda que manipulam a linguagem artística para a automatização da visão de mundo. Sofisticando-se os métodos, institui-se o juízo de gosto sobre o que é considerado como arte maior e arte menor. $\mathrm{O}$ cinema hollywoodiano, por exemplo, produz as suas próprias paródias, preenchendo 'também' esse espaço de juízo crítico que poderia ser transferido ao telespectador. A arte como recurso utilitário da arte-propaganda tem, portanto, papel fundamental na automatização da linguagem.

A finalidade da arte éde romper com a automatização mediante o estranhamento ${ }^{5}$. O estranhamento trata de particularizar a experiência da percepção estética sobre as imagens, para que o contato com a arte seja um procedimento particularizado, dificultoso e lento. As imagens tornam-se dispositivos singulares de percepção, em oposição aos dispositivos automatizados pelo cotidiano. A linguagem poética, na sua condição de estranhamento, entra em oposição ao cânone, e não a favor dele ou das instituições que o financiam. Desse modo, o estranhamento afasta o objeto do modo habitual de ele ser visto ${ }^{6}$.

A origem do termo "estranhamento", no contexto do Formalismo russo na segunda década do século XX, vem de ostranenie, derivação livre da palavra em russo ostranit. Aqui o termo é desenvolvido como procedimento de desautomatização do olhar habitual pelo afastamento do objeto da sua identidade, na dialética da não-identidade, ou seja, na negação do modelo.

As escolas de arquitetura produzem a automatização da sua visão de mundo pela reprodução do ensino da perspectiva renascentista enquanto verdade. As técnicas da perspectiva linear renascentista, desenvolvidas a partir da geometria euclidiana clássica, são reconhecidas como a representação verdadeiramente adequada do mundo. Predomina a ideia de que a idade média seja o meio entre duas épocas áureas e a perspectiva linear, o recurso autêntico. Diante da supremacia dos métodos de
4

ROSA, Maria de Lurdes. Fazer e pensar a história medieval hoje: guia de estudo, investigação e docência. Coimbra: Imprensa da Universidade de Coimbra, 2017.

5 Segundo Chklóvski, no ensaio " $A$ arte como procedimento". In: TODOROV, 2013.

\section{6}

KOTHE, Flávio R. Literatura e Sistemas Intersemióticos. São Paulo: Cortez Autores Associados, 1981, p. 170. 


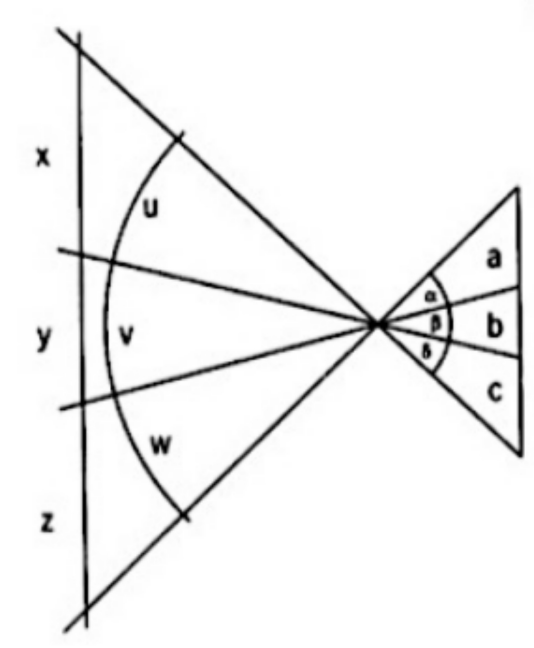

FIGURA 1: A perspectiva da retina. PANOFSKY, Erwin. La perspectiva simbólica. Barcelona: Tusquets Editores S.A., 2010.

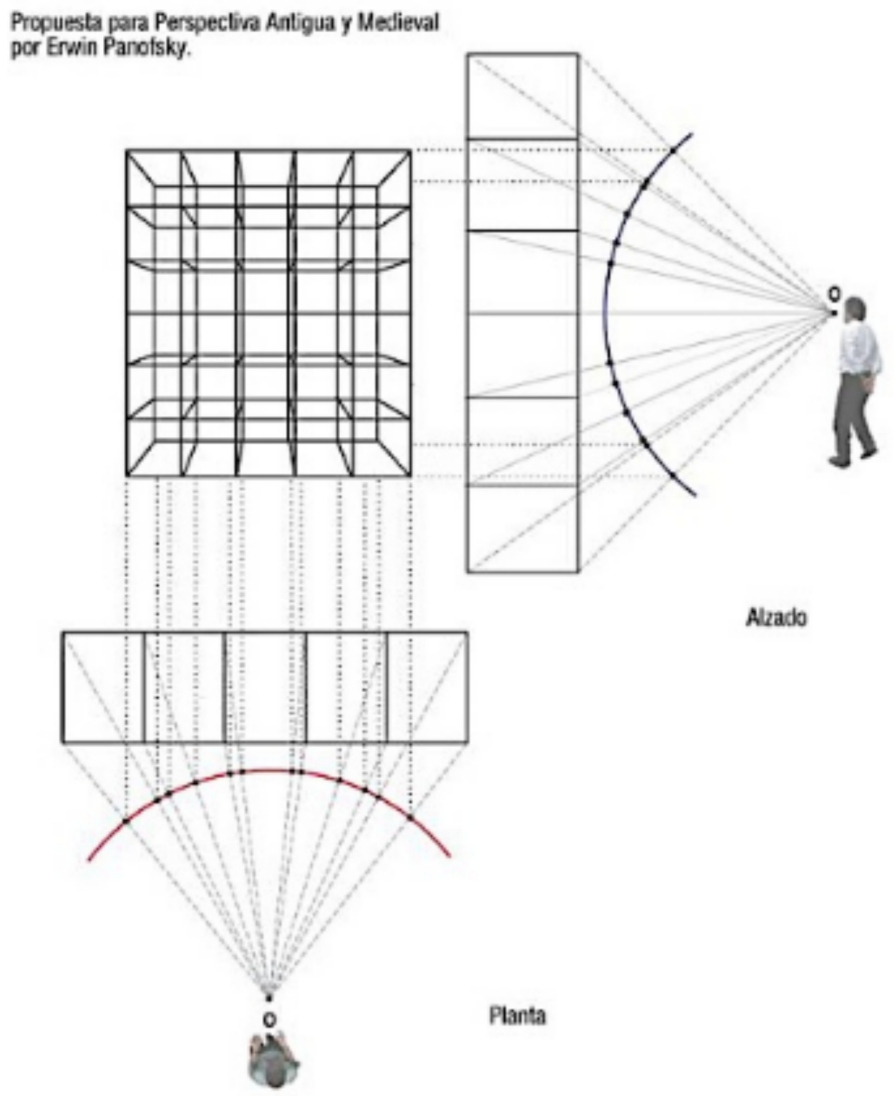

FIGURA 2: A perspectiva da retina comparada com a perspectiva linear. Disponivel em: http://www.calderononline.com/trabajos/perspectiva.htm representação chamados de corretos sobre os ditos não-corretos, os modos de representação usados na arte medieval se apresentam como inferiores e rudimentares.

As técnicas de representação tridimensional entendidas hoje como a "perspectiva projetiva"7 foram estabelecidas a partir do renascimento. Apesar dos períodos históricos serem desdobramentos dos sistemas de classificações, há uma distinção evidente nas técnicas perspectivas entre os séculos XV eXVI, quando os artistas tentaram efetivamente decifrar as leis da ótica pela representação em dois planos.

A perspectiva projetiva ou a geometria projetiva é um desdobramento do espaço euclidiano em direção à imitação da visão humana pela representação dos elementos no infinito e pelas projeções cônicas renascentistas. A partir do século XVII, a geometria projetiva, a partir da teoria da geometria descritiva ou mongeana ${ }^{8}$, formaram as bases para a representação tridimensional em dois planos, ou seja, o desenho técnico no campo do design de produto, das engenharias e da arquitetura. As plataformas digitais obedecem às mesmas premissas a partir da programação algorítimica.

Erwin Panofsky ${ }^{9}$ faz uma distinção entre "imagem perspectiva”, como artifício humano, e "imagem da retina", formada pelo sistema ocular. Dentre as suas diferenças, uma é plana e a outra é côncava (Figura 1 e2). A mente humana não reconhece as correções que a imagem da retina faz para que a imagem real se adeque ao sistema ocular humano. Não há um sistema ótico artificial idêntico ao humano, apesar do esforço de físicos e artistas, ao longo da história das artes e das ciências, tentarem decifrar as leis naturais. Para tanto, desenvolveram-se esquemas abstratos e simulações da visão humana a partir do uso de lentes côncavas em dispositivos analógicos e digitais.

Hoje, o que há de mais aproximado à experiência visual ocular são os dispositivos de realidade aumentada. A visão humana é imitada pela ilusão cenográfica de múltiplos pontos de vista num espaço de tempo, seja pela mobilidade do observador a partir de dispositivos e acessórios ergonômicos, onde há o envolvimento do corpo na realidade virtual, seja pelo uso de avatares. Essa tecnologia alcançou considerável aproximação da imagem perspectiva com a imagem da retina humana na produção do cinema e dos jogos eletrônicos. 


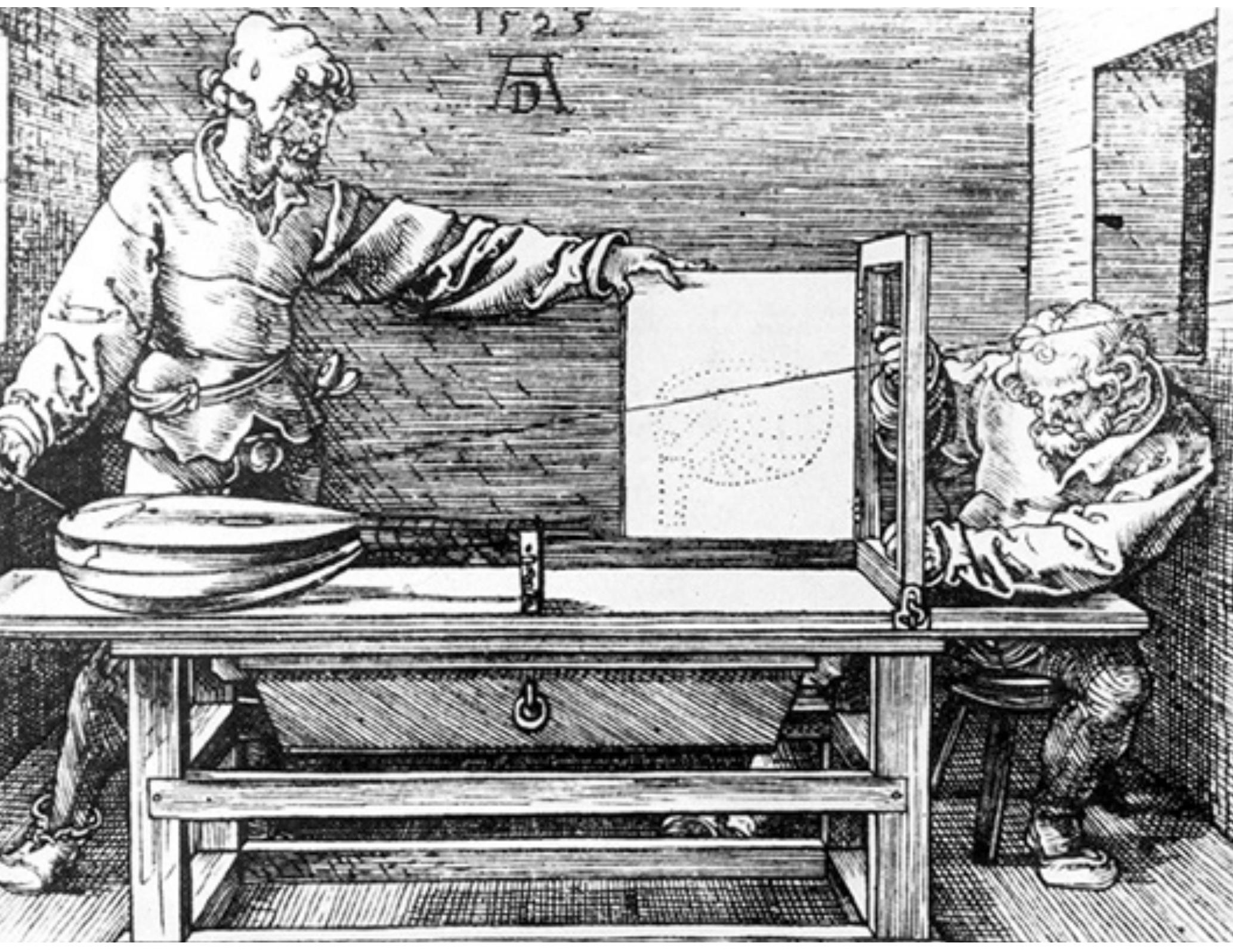

FIGURA 3: Máquinas perspectivas. Albrecht Durer

Disponivel em: https://commons.wikimedia.org/wiki/File:358durer.jpg

Os dispositivos domésticos, entretanto, ainda denunciam as distorções da perspectiva plana, assim como a maioria dos programas de modelagem arquitetônica digital, que ainda tem em seus algoritmos os princípios da geometria descritiva e da perspectiva linear. Por isso, as imagens produzidas "vazam", estouram ou se deformam artificialmente, a ponto do olho humano não reconhecer ali uma imagem idêntica à real.

A câmera fotográfica também produz imagens distorcidas. O fotógrafo desenvolve diversos recursos técnicos e artísticos para corrigir as deformações indesejadas. Dentre os recursos de correção das imagens, estão as lentes côncavas, que foram usadas pelos artistas no renascimento nas máquinas perspectivas ${ }^{10}$ (Figura 3). As curvaturas produzidas por estes dispositivos tentavam imitar a adequação óptica da imagem real captada pelo olho humano.

Os artistas tentaram exaustivamente, por séculos, imitar a imagem do olho e a complexa qualidade da visão humana nas pinturas. As regras modelares da perspectiva planificada deformam a perspectiva da retina, mas também servem de base para que os artistas façam suas "correções" (ou melhor, violações)
A perspectiva ou geometria projetiva foi definida pelo Tratado das Propriedades Projetivas das Figuras no ano de 1822, por Jean Victor Poncelet, que foi discípulo de Gaspar Monge, criador da geometria descritiva. Partindo dos principios da geometria descritiva, a geometria projetiva é uma aproximação entre a geometria euclidiana e a geometria analítica. Tem aplicação principalmente nos campos das engenharias e da arquitetura. 
A geometria mongeana ou geometria descritiva, também chamada de método de Monge,

foi desenvolvida por Gaspard Monge (1746-1818). Trata-se de um ramo da geometria que tem como objetivo representar objetos de três dimensões em

um plano bidimensional e, a partir das projeções, determinar

distâncias, ângulos, áreas e

volumes em suas verdadeiras grandezas. É a base do desenho técnico em arquitetura, design e nas engenharias, inclusive serve

de fundamento para a

programação algorítmica e vetorial nas plataformas do tipo Computer-aided design (CAD) e Building Information Modeling (BIM).

9

PANOFSKY, Erwin. La perspectiva simbólica. Barcelona: Tusquets Editores S.A., 2010.

10

As máquinas perspectivas foram estudadas e desenvolvidas principalmente por Albrecht Durer, utilizando o auxílio de lentes, espelhos e aferidores.

Sobre elas, ver Floriênsky, $A$ perspectiva inversa, e Panofsky, La perspectiva simbólica.

FLORIÊNSKI, Pavel. A perspectiva Inversa. São Paulo: Editora 34, 2012.

SKLOVSKY, Victor. La Disimilitud de lo Similar. Madrid, Alberto Corazón Editor, 1973.

FLORIÊNSKI, Pavel. A perspectiva Inversa. São Paulo: Editora 34, 2012, p.38 imitando a experiência humana de ver o mundo. Tais adequações passam por violações dos modelos geométricos da perspectiva linear mais em direção à qualidade artística e menos à fidelidade técnica.

O conceito da perspectiva inversa ou invertida foi desenvolvido por Pável Floriênsky ${ }^{11}$, em 1919, no estudo das pinturas dos ícones russos da Renascimento, aproximando-se do conceito de perspectiva iconográfica citada por Victor Sklovsky ${ }^{12}$. A perspectiva inversa, como recurso artístico, é apresentada pelo autor russo como uma contraposição à perspectiva linear euclidiana, que foi usada largamente na antiguidade clássica, mas teve sua consolidação enquanto técnica de precisão no renascimento italiano. Junto às violações cometidas pelos próprios pintores renascentistas sobre as regras da perspectiva linear - como Da Vinci ou Rafael -, Floriênsky classifica a perspectiva inversa como um procedimento de "elevação" da obra de arte.

Na Figura 4, vê-se um quadro comparativo entre a perspectiva linear, a representação axonométrica (ou cavaleira) e a perspectiva inversa de Floriênsky. A perspectiva linear se caracteriza pela simetria na representação de um ponto de fuga situado na profundidade do quadro, deformando os objetos de acordo com a distância do observador. Os objetos distantes são menores que os próximos ao observador, e este está alinhado ao ponto de fuga. Na perspectiva axonométrica ou cavaleira, os objetos não são deformados em sua profundidade: traçam-se linhas paralelas que aproximam o objeto do observador, não apresentando ponto de fuga, nem simetria. Na perspectiva inversa, o ponto de fuga é situado diante do observador, fora do quadro. Os objetos distantes se tornam próximos e os próximos, distantes do observador (Figura 5e6).

As pinturas medievais apresentam muitas vezes as três técnicas numa mesma composição, somando-se ainda a representação plana (bidimensional). Com a "descoberta" das leis da perspectiva linear pelos humanistas no renascimento italiano, a pintura realista e as representações arquitetônicas desenvolveram o discurso de uma adequação visual entre representação e verdade. A geometria euclidiana responderia às aspirações miméticas da arte, enquanto os arquitetos renascentistas idealizariam a paisagem construída a partir da paisagem representada pelas pinturas. Tal inversão genética, em que a cenografia, que representa o espaço ideal, é o cânone da arquitetura, institui-se a partir da modernidade, quando a representação técnica toma a frente da concepção arquitetônica.
Na Figura 7, vê-se um desenho do tipo "registro técnico" sobre fortalezas e castelos medievais portugueses, feito no século XV, onde são identificáveis as três técnicas citadas. Trata-se de um período de transição na história da representação arquitetônica, quando os recursos do desenho e da pintura simbólicos ainda não se submetiam às deformações da perspectiva renascentista dita científica.

Como resultado, tem-se uma composição coerente como discurso e registro, porque que são preservadas ao mesmo tempo a unidade e o particular - o conjunto na paisagem e os objetos/figuras essenciais ao registro. Seja pela análise técnica ou pela análise periódica, tal representação é considerada incorreta pela ausência dos procedimentos entendidos como realistas. As divergências sobre o tema pedem uma revisão do conceito de representação na perspectiva medieval.

A perspectiva linear, de acordo com Floriênski, não surge da arte pura, que tem essência metafísica, mas tem sua raiz nos cenários do teatro grego, como arte teatral aplicada, de efeito decorativo, em que a pintura ficava subordinada à encenação. O cenário, em qualquer contexto, não expressa a percepção artística da realidade: é dela um simulacro que usa o recurso da verossimilhança da aparência. A estética dessa aparência não representa a realidade, mas uma ilusão encenada para um espectador que, assim como o prisioneiro da caverna de Platão, está preso à sua cadeira, na plateia. Na verdade, ele em si não está preso, mas a sua vontade é que está paralisada. Diante da ilusão visual produzida pelo cenário, o espectador se torna um olho imóvel ${ }^{13}$.

Na perspectiva linear renascentista, a localização coincidente entre o ponto de vista e o ponto de fuga gera um efeito frontal de simetria entre espaço e observador. Este está predeterminado a olhar por um único ponto de vista. O interesse, ou seja, o ponto de fuga, está inserido no interior da obra. $\mathrm{O}$ alinhamento entre ponto de vista e ponto de fuga coloca o observador numa posição de dominado e o artista numa posição de dominante do espaço-cenário representado.

Essa coincidência não é encontrada nas pinturas clássicas e medievais: pelo contrário, nos afrescos das casas de Pompeia e nas pinturas e desenhos medievais é recorrente a multiplicidade dos pontos de vista (e de fuga). O mesmo acontece na perspectiva iconográfica. Diferente da perspectiva linear, que contém o ponto de vista dentro do quadro, a perspectiva iconográfica faz a figura ir até o observador (Figuras 5 e 6 ). 

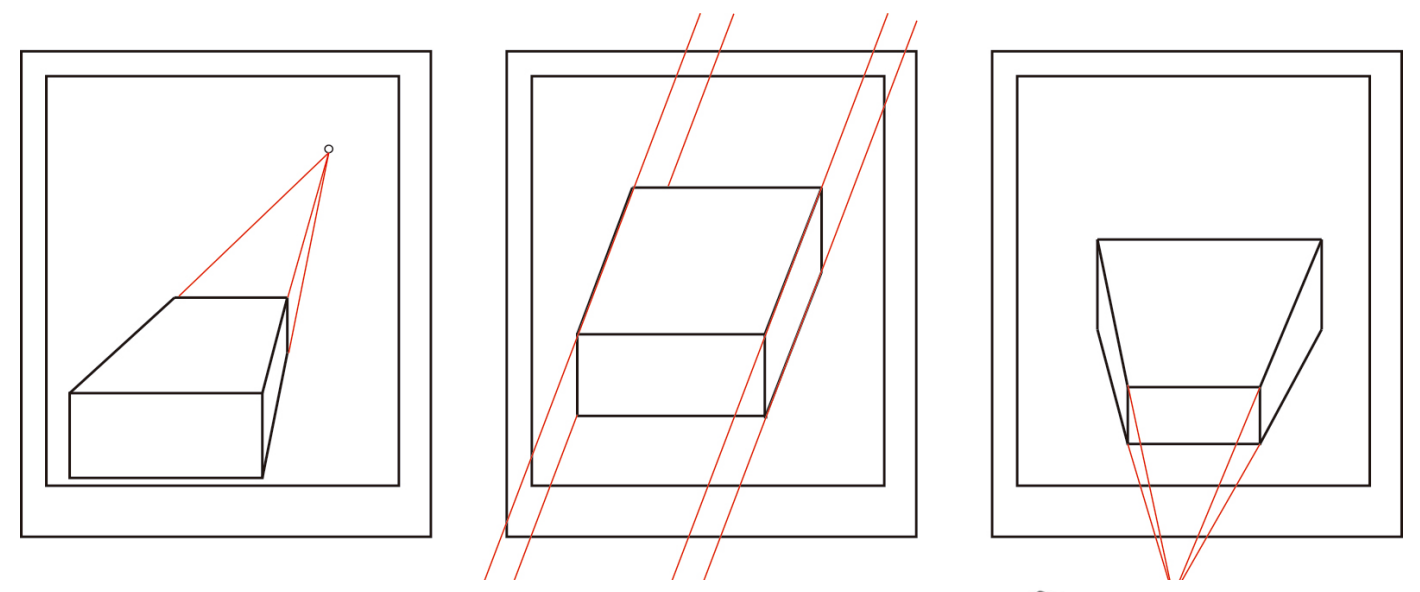

FIGURA 4: Quadro comparativo. Disponivel em:

http://www.atelier-st-

andre.net/es/index.html

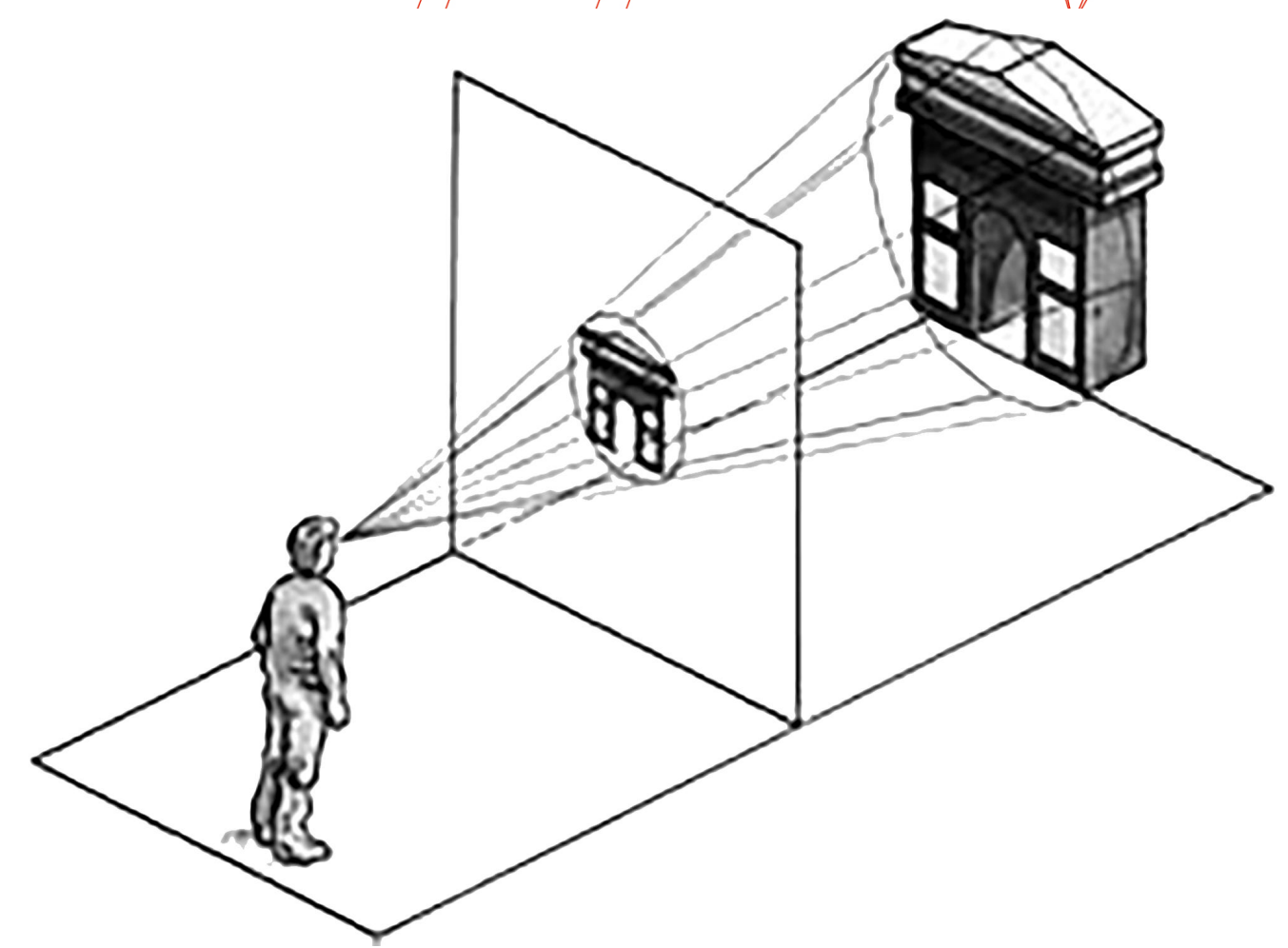

FIGURA 5: Perspectiva inversa. Disponivel em:

http://www.atelier-st-

andre.net/es/index.html
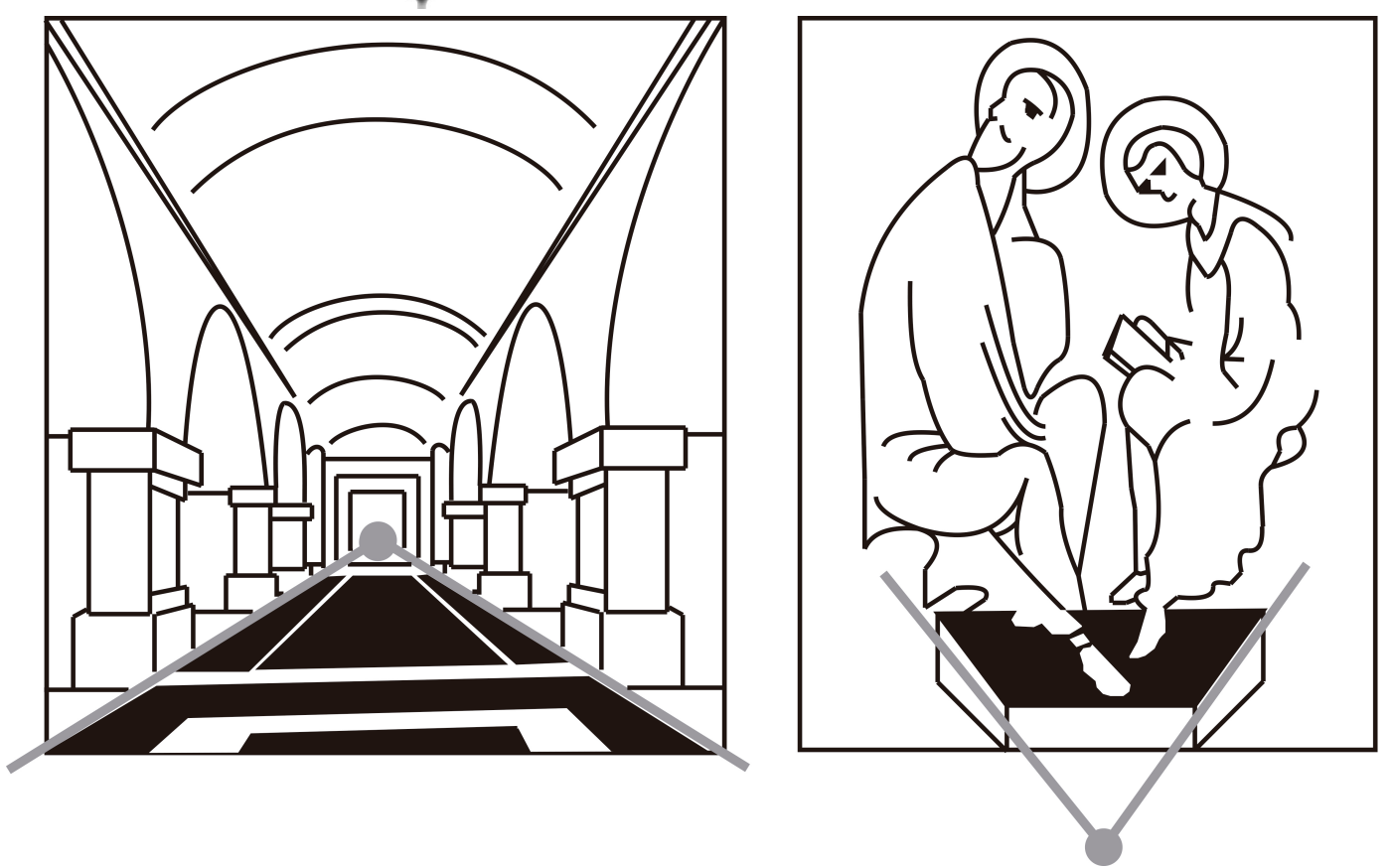

FIGURA 6: Perspectiva linear e perspectiva inversa. FLORIÊNSKI, Pavel. A perspectiva Inversa.

Trad. Neide Jallageas. São Paulo: Editora 34, 2012. 
FIGURA 7: Registro de fortalezas e castelos

portugueses, século XV. Disponivel em: http:// digitarq.dgarq.gov.pt/details?id=3909707
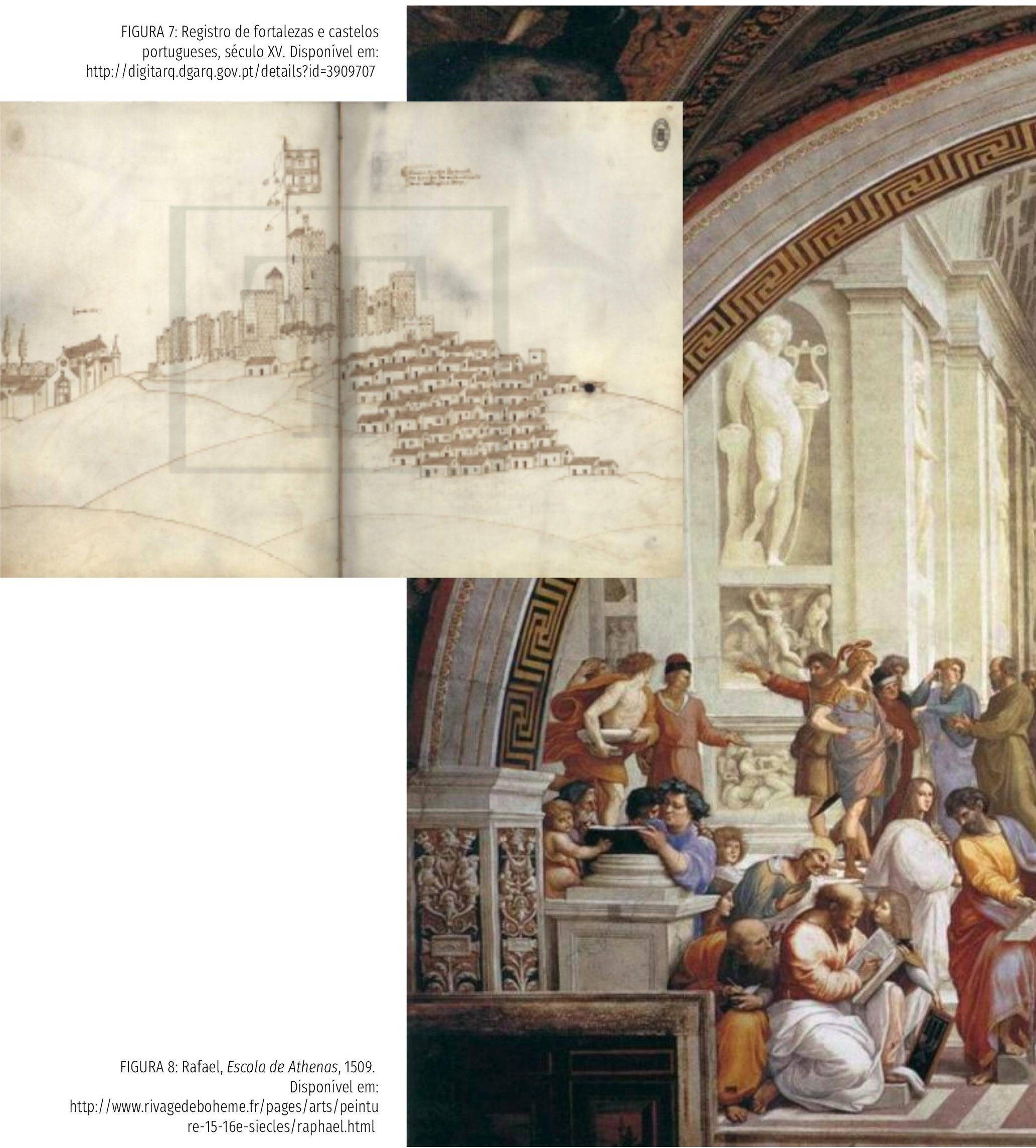

16 Revista Estética e Semiótica | Volume 8 | Número 1 


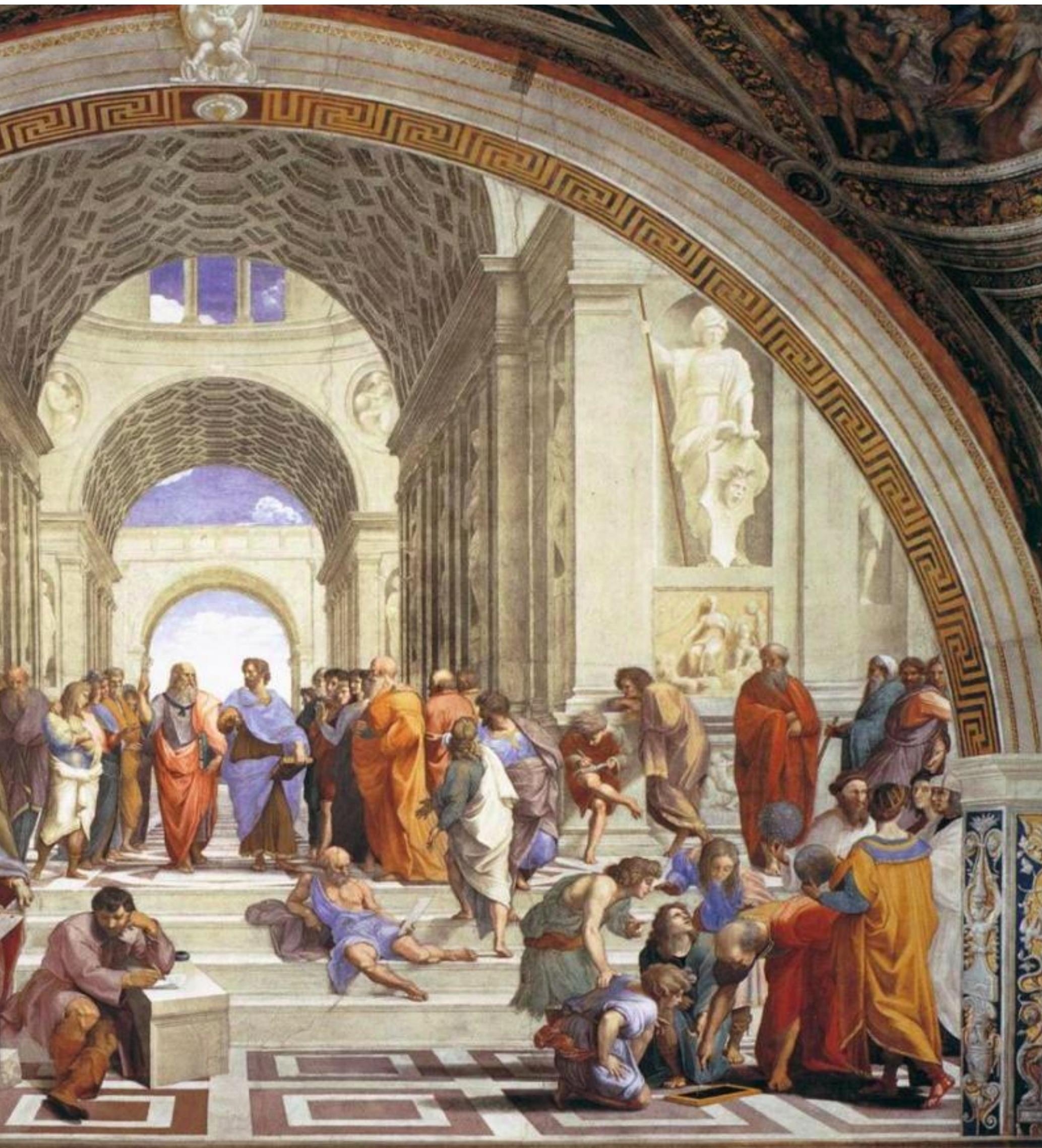


FIGURA 9: Análise da perspectiva da Santa Ceia, Da Vinci.

Disponivel em: http://www.atelierst-andre.net/es/index.html

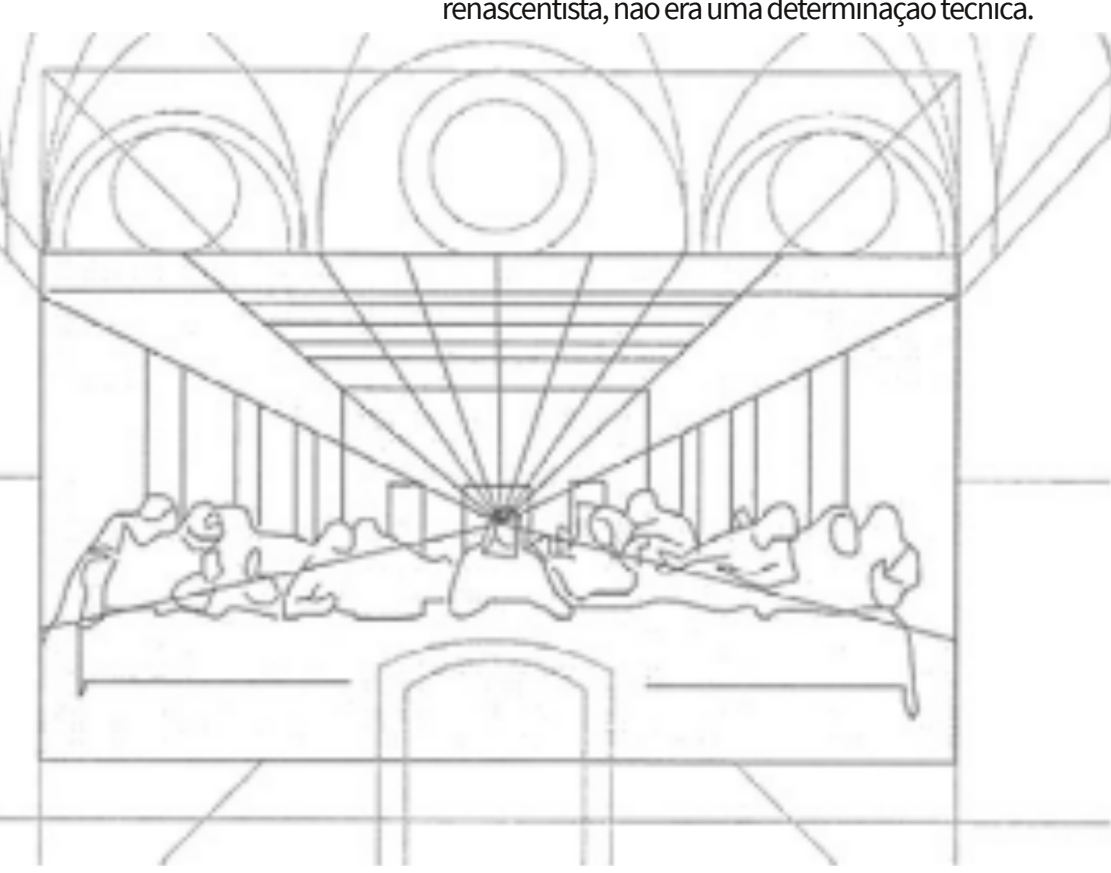

SKLOVSKY, Victor. La Disimilitud de lo Similar. Madrid, Alberto Corazón Editor, 1973, p.63-64)

FLORIÊNSKI, Pavel. A perspectiva Inversa. São Paulo: Editora 34

Ver análise do auto sobre as obras da Da Vinci, A última ceia, 1498, e Rafael, Escola de Atenas,

1510 In: FLORIÊNSKI, Pavel. A perspectiva Inversa. São Paulo: Editora 34, 2012.
Os artistas e filósofos gregos atribuíram bastante importância para a simetria, mas questionaram a perspectiva linear enquanto procedimento. Platão, no seu diálogo "O sofista", admite que, quando os pintores criam uma simetria racional dos objetos, sabem que os mais elevados são menores que os mais distantes, mas sabem também que as proporções verdadeiras afastam as pinturas da realidade, pois se baseiam na simples aparência das coisas, e não no que elas realmente são. A questão central era como as figuras distantes deveriam ser representadas. Apesar de reconhecer a grande importância da simetria e da geometria, Platão refuta as reduções da perspectiva e recorre às representações pictóricas das obras arquitetônicas, as quais tem proporções determinadas pela geometria ${ }^{14}$. A perspectiva linear clássica, portanto, ao contrário da perspectiva renascentista, não era uma determinação técnica.

Floriênski defende a violação da perspectiva geométrica como recurso artístico que supera a técnica em direção à diferenciação da obra. Tais violações, segundo o autor, revelam a liberdade do artista a favor da arte, não da técnica em si. O autor propõe que "se tome de vez o caminho do simbolismo": a potência de uma imagem é sua dimensão simbólica e não de representação da realidade, pois as representações são, por natureza, abstratas. A técnica da perspectiva inversa é apresentada pelo autor como o meio de expressão e aproximação da realidade perspectiva "verdadeiramente autêntica", pois obedece a uma ordem simbólica coerente com a sua realidade ${ }^{15}$.

A ordem simbólica ou semântica também é usada nas pinturas renascentistas, mas de forma oculta, sutil, como um disfarce. A regras da perspectiva em grandes obras de mestres como Da Vinci ou Rafael são subvertidas pela ótica da geometria. Em Rafael (Figura 8), basta medir a altura das arcadas nos planos de fundo e nos planos frontais, onde as figuras ao fundo são propositalmente mantidas em tamanho maior que o proporcional. Se fossem submetidas às regras da perspectiva euclidiana, estariam menores, distantes do observador e, portanto, fora do enquadramento desejado pelo artista. Já em Da Vinci (Figura 9), há nitidamente a deformação da proporção do edifício em relação à cena, para que os olhos do observador sejam mantidos ali, naquela mesa, naquela sala. A sala retratada pelo artista na Santa Ceia está, portanto, deformada e irreal, segundo os critérios geométricos estabelecidos pelos pintores renascentistas ${ }^{16}$.

A ordem semântica como recurso artístico intencional ou como interpretação da obra pode ser mais autêntica que a geométrica, porque transfere a ordem de importância para uma proporção artística, resultando numa composição coerente - muitas vezes hermética. O termo perspectiva apresenta nesse contexto dois sentidos: 1) perspectiva como técnica de representação tridimensional, que possibilita a ilusão de espessura e profundidade das figuras de uma composição, de um objeto, de uma cena ou de uma paisagem - técnica recorrente nas artes visuais, e 2) perspectiva como visão de mundo (ver através de), ponto de vista, concepção ou interpretação.

Numa primeira leitura, há na visão de mundo de Florênsky a dicotomia entre religião e ciência, representadas respectivamente pela arte prérenascentista e a arte renascentista, que pode ser "resolvida" pela perspectiva inversa, como síntese entre os dois polos: o simbólico e o mimético. Numa segunda leitura, há a tentativa de inversão de cânones: rebaixa-se a representação espacial renascentista como artifício humano cenográfico, trazendo a representação simbólica religiosa como autêntica, ou seja, mais elevada.

Os artistas, sejam eles clássicos, medievais ou renascentistas, deformam a geometria em razão dos princípios artísticos e da ordem semântica entre os elementos da composição. A proporção entre a figura humana e o edifício varia de acordo com princípios de enquadramento não geométricos, ou seja, a escala real não é obedecida. As figuras em destaque saem da proporção real para que tenham o protagonismo adequado à ordem semântica estabelecida. De qualquer modo, toda técnica artística é a representação da realidade e não ela mesma. 


\section{Perspectiva e montagem}

As representações do espaço são procedimentos de automatização da visão de mundo, em que as técnicas produzem identidade entre realidade e ficção. A pintura dos ícones tem uma potência cinematográfica, assim como o cinema explora o espaço iconográfico, ambos envolvendo o observador-fiel em uma narrativa fictícia que parece ser verdadeira.

A cenografia - no teatro, cinema ou televisão - é um dispositivo criador de simulacros, que repete e sofistica seus recursos miméticos e simbólicos. Os cenários apresentam-se como telas hiper-realistas esgotados pelo excesso. A arquitetura, como sistema de representações e simulacros, exerce a sua dimensão cenográfica quando toma a ficção por realidade - utopias -, ou a realidade por ficção distopias.

A arte e a ficção são recursos criadores de mitos. A arte sempre é ficção, assim como a historiografia, que se constitui num complexo sistema de representações. A verdade, na visão da historiografia, se adequa ao seu contexto ou ao sistema que a valida. Se a verdade se adequa, não pode ser "verdadeira”, e sim ficção, fábula, uma alegoria da realidade - que pode revelar traços e iluminuras da verdade.

A alegoria é uma figura de linguagem que se estende da literatura para as outras artes como a escultura ea pintura. É a representação concreta de uma ideia abstrata. A leitura alegórica é um recurso de estranhamento no sentido da desautomatização da visão habitual de determinada obra.

As alegorias em suas aparições costumam provocar estranhamento, já que se distinguem da linguagem comum, literal. A sua natureza é de dizer o outro, e por isso, à primeira vista, ela é estranha, fechada em si, inicialmente hermética. Costumam aparecer destacadas pela forma ou pela complexidade incomum. Na poesia, iniciam em letra maiúscula, por exemplo, e esse é o recurso para se provocar o estranhamento, como um aviso de que há algo a mais ali que o óbvio significado da palavra.

A alegoria integra o símbolo, superando-o pela sua transcendência. A aura valoriza o símbolo em si, enquanto o alegórico oculta a interpretação simbólica imediata, dificultando-a, a fim de transcendê-la. A alegoria é feita de contradições e a sua tendência é de ocultá-las para dificultar o desvelamento. Trata-se de um recurso artístico que driblou a censura em todos os períodos da história da arte; somente a leitura alegórica discerne e desvela tais contradições.

O alegórico é o reverso do aurático. Enquanto a aura traz o distante para perto, a alegoria transporta o próximo para tempos e lugares distantes, mediando a interpretação. São dois conceitos antagônicos e ao mesmo tempo complementares, que guardam o traço comum de serem a representação do "outro". O outro da alegoria é o outro reprimido, enquanto que o outro da aura é a representação de uma superioridade sacralizadora sob a aparência de proximidade ${ }^{17}$.

Por isso, a arte aurática pode ser entendida como a expressão da classe dominante, satisfeita por sua dominação, enquanto que a arte alegórica oculta a expressão reversa, tanto da classe dominante quanto da dominada, a partir das chaves hermenêuticas presentes na obra, as quais tensionam idealismo e materialismo, espírito e corpo, eterno e transitório, significado e significante.

A aparição alegórica diz outra coisa, além de si, e para tanto usa a linguagem figurada, indireta, geralmente metafórica. Como um jogo de interpretação, a estrutura alegórica se mostra difícil, plana e hermética. É o fator de estranhamento que provoca o hermeneuta a desvendar o jogo, o mistério. Para o crente, a alegoria em si é a verdade, e sua estrutura, o fator divino que a mantém; não é do seu interesse desvelar o que está oculto, e sim afirmar a sua condição de velamento, porque a verdade deve ser um privilégio.

Para o hermeneuta, a alegoria é uma figura ou recurso de linguagem que preserva uma constelação, um sistema a ser descoberto. Numa visão mais ampla, a alegoria pode ser um recurso de síntese para os campos da retórica, da literatura e da estética; um fragmento do todo, pois guarda em si as tensões e as contradições da obra de arte, da história e da teoria ${ }^{18}$.

A leitura de tais contradições recupera a totalidade da alegoria como obra e como recurso artístico. Enquanto a alegoria pode ser entendida aqui como instrumento de automatização da visão de mundo dominante, a leitura alegórica é um recurso de estranhamento das convenções, ou seja, da visão de mundo automatizada, desconstruindo a alegoria.

A pintura dos ícones russos revela não somente os seus procedimentos artísticos, mas a consolidação de uma tradição que se fortalece na sacralização da obra de arte. A rejeição da perspectiva pré-renascentista pelos
17

KOTHE, Flávio R. A alegoria. São Paulo: Editora Ática, 1986; KOTHE, Flávio R. Para ler Benjamin. Rio de Janeiro: Francisco Alves Editora, 1976

18

KOTHE, Flávio R. A alegoria. São Paulo: Editora Ática, 1986. 
pintores iconógrafos não se explica pelo isolamento geográfico ou cultural; estes tiveram contato com os pintores italianos nos primórdios do renascimento. 0 que os pintores pretendiam investigar eram certos problemas espirituais; verdades essas diferentes das que os pintores renascentistas perseguiam com o desenvolvimento das técnicas de representação mimética pela perspectiva linear.

O conceito de "ícone" nas pinturas iconográficas se confunde ao de "mito", justamente por ter sido atualizado, retirado do seu contexto de origem. A pintura iconográfica pode ser compreendida como um procedimento de consolidação da tradição mítica, a partir da automatização da linguagem da iconografia, na qual o artista é apenas um instrumento divino, semelhante à pintura egípcia. Nesse sentido, o ícone consolida-se como obra aurática, que aproxima o distante.

A palavra "ícone" vem do grego eikôn, que significa “imagem", "retrato'. O nascimento de Cristo marca o nascimento do ícone: o verbo se fez carne, O Invisível se tornou visível, Deus tomou uma forma humana ${ }^{19}$.

Disponivel em http://www.atelier-standre.net/es/index.html artes visuais. São Paulo: Perspectiva, 2017, p. 53. O ícone enquanto procedimento artístico é produto da tradição, desenvolvido historicamente pelos pintores iconógrafos. O artista é visto como um instrumento da representação do divino; as pinturas se apresentam como obras que vão além da abstração sensível do autor, elas contêm uma aura. Não há, portanto, uma preocupação com a autoria das obras, e sim com a preservação dos saberes artísticos pelo uso contínuo da mesma linguagem, como uma escrita sagrada.

A iconografia, que vem do grego eikô e graphein, implica num método de descrição e classificação das imagens, sendo necessária como método de registro histórico, mas limitada como sistema de interpretação simbólica. Ela não investiga a gênese, a interação entre os tipos, a correlação entre presenças e ausências, o que está aparente e o que está oculto nas imagens; considera uma parte de todos esses elementos intrínsecos de uma obra de arte. A descoberta e a interpretação dos valores simbólicos, ou seja, o extrínseco da obra de arte, são objetos de uma “iconologia”, em oposição à "iconografia”20.

A aura dos ícones, como imagens, é reforçada pela unidade entre forma e conceito, que traz para perto o distante. As composições iconográficas, no entanto, são narrativas que transportam o observador próximo para tempos e lugares míticos distantes. Tais obras apresentam ambiguidades e recursos artísticos ocultos que são passíveis de uma leitura alegórica.

Na representação iconográfica de Ohrid sobre a Anunciação (Figura 10 e 11), do século XIV, os ícones estão representados em primeiro plano, sobre pedestais. O pedestal do Arcanjo e o pedestal da Virgem Maria estão desenhados em perspectiva inversa, ambos trazendo os ícones para perto do observador ${ }^{21}$. A caixa cênica se deforma para que o observador o contemple de diferentes pontos de vista. o cenário, que representaria acontecimentos no interior dos edifícios, é deformado para sugerir uma exteriorização das cenas, como se a arquitetura fosse o palco. Assim, as deformações do cenário permitem a melhor elaboração da narrativa, porque a representação do espaço tem um papel posterior, ou seja, não é ele quem parece ditar as regras. Essa técnica de composição permite que se crie uma proporção de ordem semântica entre as figuras, segundo sua importância hierárquica dentro do sistema.

O estranhamento provocado pelos ícones faz parte desse jogo de distanciamento e aproximação. A ausência do realismo mimético na representação do espaço iconográfico parece permitir ao observador fazer parte da cena representada na pintura - trata-se de um recurso cenográfico. Os ícones e fiéis entreolham-se durante a narrativa do culto ou da caminhada pelo interior do templo, numa constante presença em movimento, aproximados pelos pontos de vistas múltiplos, aparentemente desordenados, mas coerentes dentro de uma narrativa ali sacralizada para além do seu tempo.

Assim como a técnica da perspectiva invertida, o conjunto de cenas que compõem a narrativa não parece ter uma lógica linear. As cenas representadas no ícone de São Nicolau (Figura 12) configuram uma narrativa circular, que, suspensa no tempo e no espaço, compõe o objeto mítico. A suspensão se dá pelo empilhamento de tempos, como um "registro próximo de algo distante" - a própria dimensão aurática da alegoria - representando ao mesmo tempo todas as épocas e nenhuma.

A representação do mito acontece pela composição cíclica e dinâmica das cenas, a partir da lógica das visuais múltiplas, enquanto que na perspectiva linear predomina a composição cenográfica estática. Ambos usam, portanto, os recursos cenográficos para melhor afirmar sua ideologia. 

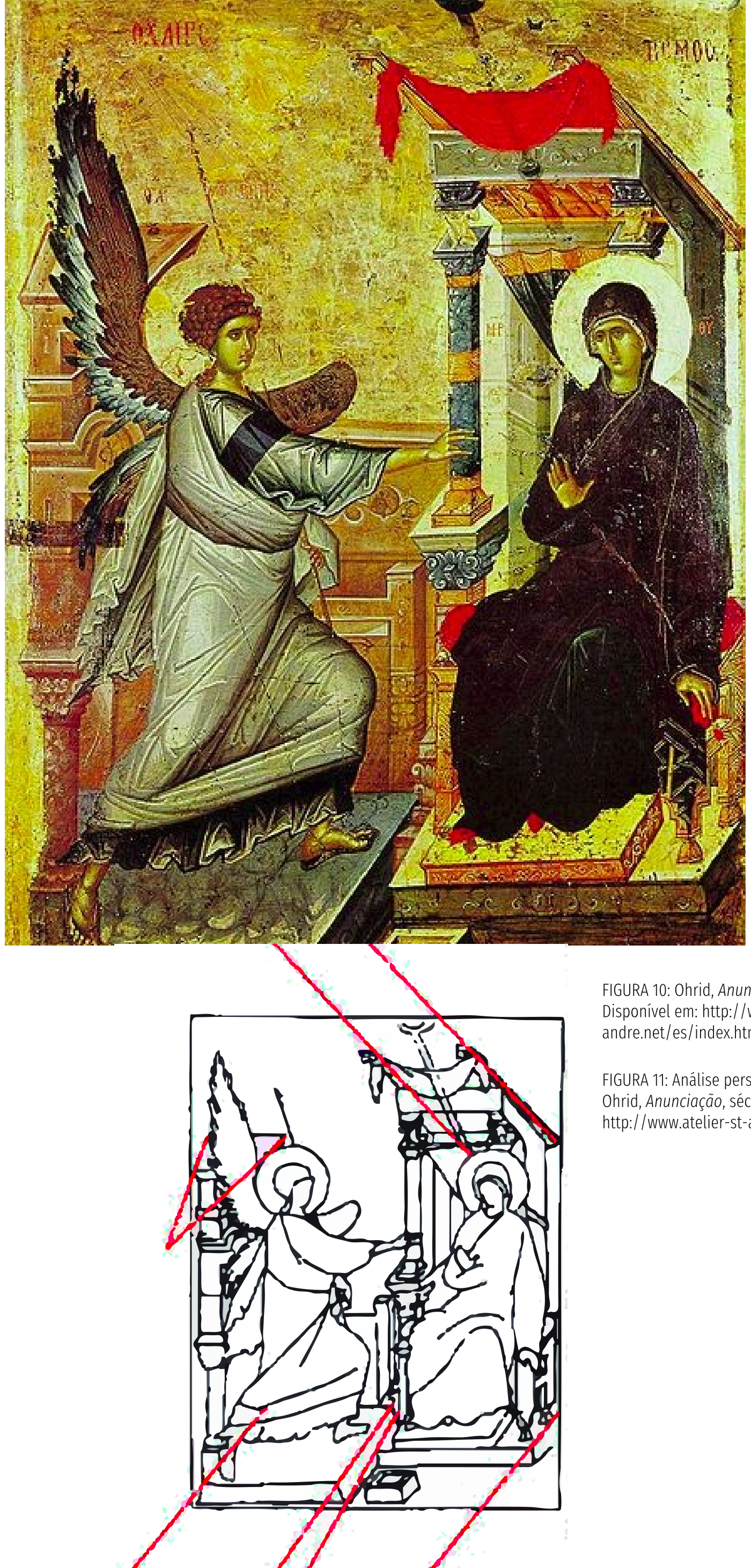

FIGURA 10: Ohrid, Anunciação, século XIV. Disponivel em: http://www.atelier-standre.net/es/index.html

FIGURA 11: Análise perspéctica da pintura de Ohrid, Anunciação, século XIV. Disponivel em: http://www.atelier-st-andre.net/es/index.html 


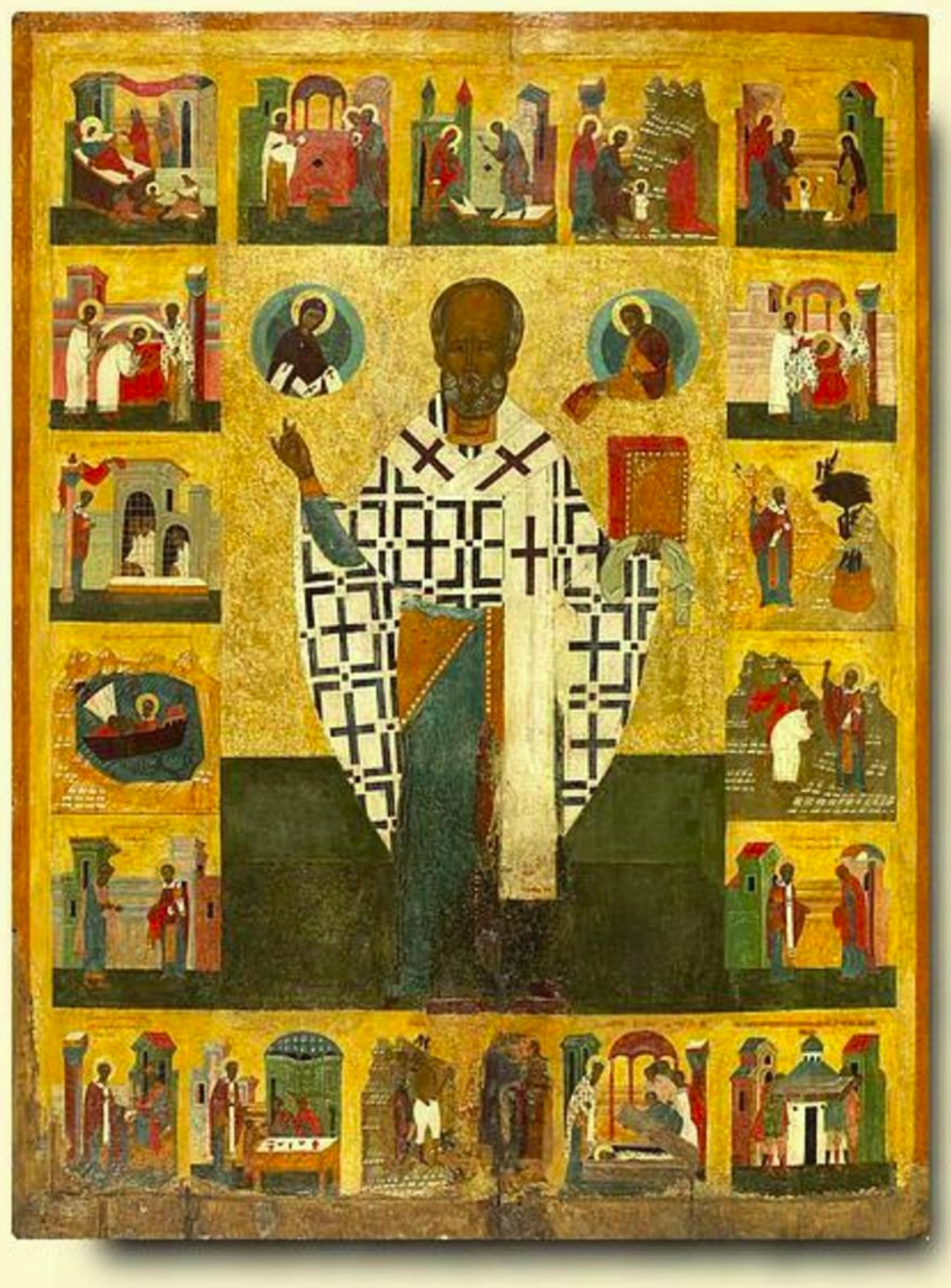

FIGURA 12: Escola de Novgorod, São Nicolau e cenas de sua vida, século XVI. Disponivel em: http://www.artfixdaily.com/images/pr/Aug30_icon902×1200.jpg

Na sua aparência de não-verdade, pela negação da arte mimética, e na condição do estranhamento provocado pelo dispositivo, o ícone em si se torna um mito, distante enquanto enunciado, por ser eternizado, e próximo enquanto recepção, pela sua presença no primeiro plano da pintura. $O$ estranhamento quanto à linguagem mais pictórica e menos realista parece ampliar o mito, mas a sua forma de apresentação, no entanto, é um modo de rebaixamento para aproximar a divindade do plano visual da escala humana, mais pelos recursos de montagem e composição e menos pela representação simbólica em si, mostrando o ícone mais próximo do que distante.
A pintura iconográfica, portanto, ao mesmo tempo amplia e reduz a distância entre o divino e o mundano. Distancia, porque o divino se apresenta como eterno, longe da compreensão histórica ou cotidiana, e aproxima, porque a composição iconográfica, com seus múltiplos pontos de vista, cria a ilusão de que o fiel é vigiado e acalentado pela presença do ícone, estando ele envolvido pela estrutura narrativa mítica.

A pintura iconográfica cria um espaço de vazio hermenêutico entre o observador e o ícone, que provoca o estranhamento na apreensão da obra. Para o fiel, essa dificuldade resulta, paradoxalmente, na 
aceitação do desconhecido como mistério divino. Distante e próximo ao mesmo tempo, essa é a composição do mito pela arte aurático-simbólica, que se propõe acima da condição histórica, absoluta.

Os ícones representados, ou melhor, encarnados num plano elevado, acima da linha do horizonte, representam sua divindade e soberania, praticamente inalcançáveis. Ao mesmo tempo, eles dialogam com o observador, pois este participa do jogo visual, mesmo que em sua posição inferior. Cada um parece saber bem o seu papel.

A tradição se consolida a partir dos seus mitos, perpetuados na linguagem simbólica dos ritos. Os procedimentos usados para a construção dessa narrativa-montagem mítica são herméticos, alegóricos, não se revelam pela montagem em si, mas a disfarça, transformando pedaços de coisas em um discurso contínuo, que parece natural. Esse disfarce geralmente tem o intuito educativo ou coercitivo que é o de se passar por dogma, ou seja, por verdade.

Ao contemplar os ícones, o fiel remonta à narrativa cristã em direção à afirmação do mito, fortalecendoo. Já o esteta desmonta a estrutura narrativa pelas chaves de leitura deixadas como rastros pelos artistas iconógrafos, a partir dos recursos alegóricos de montagem. Entre o seu conteúdo manifesto e oculto, a leitura alegórica expõe o elemento simbólico ao estranhamento, de modo que o observador se sinta desafiado ao refazimento da narrativa e à sua dessacralização.

A arte medieval é estudada equivocadamente de pontos de vista isolados, seja pela sua autenticidade como registro historiográfico, seja como relíquia religiosa. Além da sua condição aurática, a obra de arte pode ser lida como uma alegoria. A partir do reconhecimento dos recursos artísticos ditos "sagrados", é possível se fazer uma leitura laica das composições, que pode revelar elementos ocultos na narrativa.

O estranhamento da pintura iconográfica medieval se dá mais pelas composições alegóricas que funcionam, nesse contexto, como imitações do sistema. Para além da iconografia estatística, as composições bizantinas figuram o sistema ideológico que as definem. A alegoria narrada, além de figuração dos cânones e da auratização dos ícones, pode ser a chave hermenêutica: ao mesmo tempo evoca e desprende a obra do seu tempo.

\section{A não-inversão da \\ perspectiva inversa}

O conceito da perspectiva inversa é uma afirmação do sistema simbólico como tradição, dogma e verdade, representados pelos ícones russos. A inversão dos cânones é conveniente à visão de mundo de Floriênsky, que era, além de matemático e filósofo, teólogo e padre da Igreja Ortodoxa.

A perspectiva renascentista questionou o cânone medieval, assim como os ícones medievais negaram a métrica dos cânones clássicos. A perspectiva inversa pretende ser um recurso de estranhamento sobre a visão automatizada de que a arte simbólica medieval é inferior à pintura realista renascentista. $O$ cânone, nesse caso, é identificado pela perspectiva linear consolidada num período posterior aos ícones russos, o renascimento. Esta é a primeira contradição.

Os artistas medievais subverteram e ao mesmo tempo imitaram os cânones clássicos, recriaram os próprios, ora rebaixando as técnicas ora elevando-as. Do mesmo modo, os renascentistas ampliaram as possibilidades artísticas medievais em direção à sofisticação da representação, seja ela mimética ou simbólica. 0 recurso da composição alegórica é evidente em ambos os períodos e se fortalece nos movimentos artísticos posteriores, como o maneirismo e o barroco.

O desconhecimento da perspectiva inversa enquanto técnica e a tomada da perspectiva linear como autêntica revelam que as escolas de arquitetura tomam o renascimento enquanto mito, e não como “construtor de mitos". Esse não é um paradigma neutro ou ingênuo, já que, além do mérito em si, toda supremacia é alcançada pela imposição de valores de um modelo sobre outro. Ao negarem os dogmas da fé, os renascentistas recriaram outros dogmas: os humanistas. Fundados sobre as mesmas bases criadoras dos mitos, a razão é tomada como religião, diferenciando-se na aparência e não na essência. Mudam os ritos e sobrevivem os mitos: o que antes era conservado pela fé no período medieval, na Renascença é regulado pela métrica. $O$ dogma se disfarça de ciência.

A idade média é estudada como um mito, de natureza simbólica e pouco científica, geralmente de conotação negativa de um passado visto apenas como o intervalo entre duas épocas áureas, a antiguidade e o renascimento. As técnicas renascentistas de representação são tomadas como autênticas e modelares, dificultando a sua leitura simbólica. A 
automatização da analítica simbólica para arte medieval, na lógica do dicionário ilustrado (que também é automatizado), ofusca o estudo dos recursos artísticos que as diferenciam entre si, dificultando a leitura das estruturas semânticas das obras. Seja pela autenticidade ou pela tradição (a aura), ambas são reduzidas aos seus próprios cânones.

A natureza da perspectiva inversa é contraditória, já que ela supõe a negação do modelo vigente e, para tanto, se coloca invertida, equivocada ou mesmo incorreta. Se esta é inversa, aquela é correta por referência. Então quem inverte afirma o invertido como ponto de partida. O estranho é que o ponto de partida é a perspectiva renascentista, que foi consolidada posteriormente. Há de certo modo uma inversão cronológica ou uma incoerência histórica na visão do autor russo.

A inversão na perspectiva inversa deveria ser analisada mais no sentido de se "estranhar" o sistema anterior clássico e menos de se usar a inversão como recurso artístico que contrapõe os cânones do renascimento. Os cânones artísticos da mitologia cristã apresentam uma dupla natureza: a de representar os ideais dominantes e a de compor alegorias que guardam as contradições e ambiguidades que só poderiam ser expressas desse modo. Os ícones russos, nesse contexto, também são canônicos.

A perspectiva inversa aparenta ser um procedimento que estranha a composição mimética do espaço em direção à uma ordem semântica, mas é também uma visão de mundo impregnada de dogmas e verdades do sistema que representa. 0 corpo, no renascimento, é projetado para o ponto de fuga em direção ao horizonte, num movimento de idealização do ponto de vista do observador. Nas pinturas dos ícones, eleé desenhado em proporções de ordem sagrada, idealizando a figura divina.

Assim como os desenhos das crianças, as pinturas na arte medieval seguem uma ordem particular. As composições seguem uma lógica que, se comparada às regras euclidianas da perspectiva linear, são consideradas incorretas. No entanto, os detalhes e os objetos obedecem a uma hierarquia de valores que correspondem ao seu peso semântico, de acordo com a sua importância e situação no quadro. O sentido é ampliado porque segue outra lógica interna: a da ordem semântica.

Ambos, porém, são representações realistas: a criança representa a proporção de acordo com a sua realidade simbólica; o faraó é representado na pintura egípcia numa proporção condizente com a realidade escravocrata, e a pintura na renascença traz o recurso do realismo mimético que oculta o seu peso semântico pelo ilusionismo, numa brincadeira cenográfica de enganar o observador (ou o fiel). Mudam-se os critérios, mas permanece a natureza simbólica das representações.

Quando a perspectiva deixa de ser um problema técnico-matemático, ela se voltar para o problema artístico ${ }^{22}$. A perspectiva inversa enquanto recurso artístico propõe a alteração da ordem da perspectiva linear, mas ao ser elevada como autêntica, entra em contradição interna, pois a sua condição de inverter a ordem sugere que a perspectiva ordenada seja a gênese do sistema. Cronologicamente, a inversa vem antes da ordenada - eis a contradição. A inversão como recurso artístico, nesse caso, parece ter sido determinada pelo distanciamento de tempo, assim como a periodização determinou a idade média. Assim, ambas estão contaminadas por certas preferências ideológicas.

A inversão como alteração da visão de mundo faz mais sentido ao se admitir que há um confronto entre ideologias: a teológica cristã e a humanista. Enquanto os artistas iconógrafos replicam os seus modelos de representação, os humanistas italianos esforçam-se em ocultá-los. O principal recurso para o disfarce, em ambos, é o aprimoramento da técnica. Ocultam-se as contradições pelos recursos artísticos, que figuram o discurso e fazem das obras de arte, alegorias. 
Referências bibliográficas

DUBY, Georges. A história continua. Zahar, 1993.

FLORIÊNSKI, Pavel. A perspectiva Inversa. Trad. Neide Jallageas. São Paulo: Editora 34, 2012.

KOTHE, Flávio R. A alegoria. São Paulo: Editora Ática, 1986.

Literatura e Sistemas

Intersemióticos. São Paulo: Cortez Autores Associados, 1981.

Para ler Benjamin. Rio de Janeiro: Livraria Francisco Alves Editora, 1976.

LE GOFF, Jacques. A história deve ser dividida em pedaços? Trad. Nicia Adan Bonatti. São Paulo: Editora UNESP, 2015.

MUKAROVSKY, Jan. Función, norma y valor estéticos como hechos sociales. Trad. Jorge Piranesi. Buenos Aires: El Cuenco de Plata, 2011.
PANOFSKY, Erwin. Significado nas artes visuais. Trad. Maria Clara F. Kneese e J. Guinsburg. São Paulo: Perspectiva, 2017.

. La perspectiva simbólica. Trad. Virginia Careaga. Barcelona: Tusquets Editores S.A., 2010.

ROSA, Maria de Lurdes. Fazer e pensar a história medieval hoje: guia de estudo, investigação e docen̂cia. Coimbra: Imprensa da Universidade de Coimbra, 2017.

SHKLOVSKY, Viktor. Theory of Prose. Trad. Benjamin Sher. Illinois: Dalkey Archive Press, 2009.

SKLOVSKY, Victor. La Disimilitud de lo Similar. Colección Comunicación. Série B. Trad. José Fdez. Sánchez. Madrid, Alberto Corazón Editor, 1973.

TODOROV, Tzvetan. Teoria da literatura: textos dos formalistas russos. Trad. Roberto Leal Ferreira. São Paulo: Editora Unesp, 2013. 
26 Revista Estética e Semiótica | Volume 8 | Número 1 